\title{
Pengaruh Pertumbuhan Ekonomi dan Inflasi terhadap Profitabilitas pada Perusahaan Makanan dan Minuman di BEI
}

\author{
Konradus Anugrah \\ Universitas Prima Indonesia \\ konradusanugrah77@gmail.com \\ Ayu Rukun Hartati Hutabarat \\ Universitas Prima Indonesia \\ ayuhutabarat30@gmail.com
}

\author{
Regina Christine Simanjorang \\ Universitas Prima Indonesia \\ reginachristine123@gmail.com \\ Rotua Juniarti Pakpahan \\ Universitas Prima Indonesia \\ rotuajuniarti@gmail.com
}

\section{Tetty Tiurma Uli Sipahutar \\ Universitas Prima Indonesia \\ ratuhapis.tetty@gmail.com}

Corresponding Author : Tetty Tiurma Uli Sipahutar

Submitted: 30 Juni 2020

Accepted: 2 Agustus 2020

Published: 2 Agustus 2020

ABSTRAK

Perkembangan perusahaan Makanan dan Minuman di Indonesia tidak terlepas dari perkembangan ekonomi. Kondisi bisnis dan pertumbuhan ekonomi adalah faktor yang mempengaruhi reaksi daya beli masyarakat. Reaksi daya beli, dalam hal ini, terlihat dalam tingkat inflasi suatu negara yang sangat mempengaruhi pertumbuhan ekonomi dan kondisi bisnis suatu perusahaan. Pertumbuhan ekonomi yang tinggi dan kondisi bisnis yang baik diharapkan memiliki dampak yang baik pada profitabilitas perusahaan. Penelitian ini dibahas untuk mengetahui pengaruh pertumbuhan ekonomi dan inflasi terhadap profitabilitas yang diukur dengan Return On Asset (ROA). Metode sampel penelitian memakai teknik purposive sampling dan menggunakan pendekatan pengambilan sampel non-probabilitas. Hasil penelitian menjelaskan bahwa Pertumbuhan ekonomi dan inflasi tidak mempunyai pengaruh parsial dan simultan terhadap profitabilitas. Pengamatan menggunakan dua variabel makroekonomi sehingga dalam pengamatan selanjutnya menggunakan variabel berbeda yang bisa mempengaruhi profitabilitas perusahaan.

Keywords : Pertumbuhan Ekonomi, Inflasi, Profitabilitas

\section{PENDAHULUAN}

\section{A. Latar Belakang Masalah}

Masalah jangka panjang yang dialami Indonesia saat ini yaitu pertumbuhan ekonomi. Terlihat dari laba perusahaan yang mempengaruhi produksi barang dan jasa. Pertumbuhan ekonomi saat ini dipengaruhi oleh peningkatan kualitas yang dapat menyebabkan peningkatan kesejahteraan rakyat. Pertumbuhan 
ekonomi suatu negara tergantung pada tingkat konsumerisme Makanan dan minuman yang juga memiliki kelebihan dibandingkan dengan kebutuhan lain, ini karena menjadi salah satu kebutuhan primer. Pertumbuhan ekonomi didukung oleh berbagai sektor yang berkontribusi terhadap pertumbuhan ekonomi di Indonesia. (Suryani et al., 2016).

Kenaikan harga nasional berdampak pada daya beli konsumen sehingga pendapatan dari semua sektor Makanan dan Minuman juga menurun. Inflasi yang tinggi menyebabkan ketidakstabilan ekonomi makro yang berdampak pada keseluruhan kegiatan ekonomi. Keadaan di mana kecenderungan fenomena keuangan di suatu negara dalam sistem kenaikan harga umumnya mengandung mekanisme pasar. Di mana tingkat harga dianggap terlalu tinggi, kelangkaan produksi, permintaan sangat cepat dari konsumen, dan terlalu banyak jumlah uang beredar mengindikasikan inflasi. Inflasi berdampak pada perusahaan yang mengakibatkan peningkatan biaya produksi atau biaya operasional sehingga dapat mengurangi laba perusahaan.

Setiap perusahaan harus menjalankan operasi bisnisnya untuk mendapatkan untung yang diperkirakan akan terus meningkat. Secara teoritis, pengaruh fluktuasi ekonomi mempengaruhi seluruh perusahaan. Pertumbuhan ekonomi yang bertambah bisa menaikkan profit perusahaan dan kondisi ekonomi makro yang berubah berpengaruh pada kemampuan perusahaan. kemampuan perusahaan dapat terlihat didalam keuntungan yang diterima perusahaan.

Meskipun suatu negara pertumbuhan ekonomi tidak salah satu faktor yang mempengaruhi kemampuan perusahaan, pertumbuhan ekonomi dianggap sebagai faktor berpengaruh didalam memengaruhi kinerja tersebut, jadi tujuan variabel ini adalah untuk mendapatkan bahwa pertumbuhan PDB memiliki pengaruh positif yang signifikansi pada profitabilitas perusahaan (Adiyadnya et al., 2016).

Inflasi menaikkan penghasilan dan anggaran perusahaan. Peningkatan dana produksi yang lebih tinggi dari kenaikan nilai jual yang diperoleh perusahaan akan berakibatatas penurunan profitabilitas perusahaan, dan kebalikkannya jika kenaikan dana produksi lebih sedikit daripada kenaikan nilai jual perusahaan (produsen), profitabilitas perusahaan akan meningkat (Eduardus, 2012).

Hubungan antara profitabilitas perusahaan dan kegiatan ekonomi saling berkaitan, masalah yang terjadi adalah jika profitabilitas perusahaan tidak efektif, pertumbuhan ekonomi tidak baik dan inflasi pada perusahaan jika selalu terjadi dapat menyebabkan kerugian fatal. Profitabilitas perlu perhatian serius, karena, jika profitabilitas rendah dan bahkan menderita kerugian dan akan berdampak negatif pada sektor ekonomi makro di Indonesia. Investor juga mengetahui kinerja keuangan perusahaan. Analisa profitabilitas adalah suatu upaya agar dapat digunakan untuk menghitung kinerja keuangan perusahaan (Kasmir, 2013).

Dengan memperoleh laba maksimum sesuai target, perusahaan dapat memberikan kesejahteraan bagi pemilik, karyawan, dan meningkatkan kualitas produk serta membuat inovasi baru. Oleh sebab itu manajemen perusahaan harus dapat mencukupi target yang ditetapkan (Kasmir, 2012).

Pertumbuhan ekonomi dinilai dari permintaan dan penawaran barang dan juga layanan bank berkaitan dari kegiatan ekonomi. Pertumbuhan ekonomi dan profitabilitas berhubungan positif yang ditandai dari permintaan yang meningkat untuk produk dan layanan bank (Alper\& Anber, 2017).

Nilai rill biaya dan penghasilan dipengaruhi inflasi. Apabila tingkat inflasi diwaspadai, bank dapat mencocokkan tingkat bunga untuk menaikkan 
penerimaan daripada pengeluaran. Sebaliknya, apabila inflasi tidak diatasi, bank tidak dapat melakukan penyesuaian suku bunga dengan tepat mampu meningkatkan biaya lebih cepat daripada pendapatan (Alper \& Anber, 2017).

Perusahaan memiliki tingkat profitabilitas dapat menaikkan kinerja perusahaan di kalangan masyarakat karena profitabiltas menjadikan elemen penting didalam setiap perusahaan (Alper\& Anber, 2017).

\section{TINJAUAN PUSTAKA}

\subsection{Teori Pengaruh Pertumbuhan Ekonomi terhadap Profitabilitas}

Produk domestik bruto (PDB) yaitu jumlah produksi produk dan jasa diproduksi oleh penduduk domestik dan asing yang tinggal di suatu negara, tidak termasuk penduduk domestik yang tinggal di luar negeri. Apabila pertumbuhan ekonomi semakin baik, daya beli masyarakat juga naik. Tetapi meningkatnya daya beli masyarakat mendorong orang untuk mengkonsumsi barang dan jasa yang tidak diikuti oleh keinginan untuk berinvestasi.

Peneliti Ekasari \& Baskara; Adiyadnya dan kawan-kawan; Ramadan dan kawan-kawan membuktikan bahwa hasil pertumbuhan ekonomi berpengaruh positif dan signifikan terhadap profitabilitas perusahaan (Ekasari \& Baskara, 2018); (Adiyadnya et al., 2016); (Ramadan et al., 2011).

Salah satu indikator ekonomi makro yang dipakai produk domestik bruto untuk menghitung total aktivitas ekonomi, bisa berpengaruh pada beragam faktor baik didalam pasokan jasa dan produk ataupun permintaan. Pengukuran variabel produk domestik bruto didasarkan pada tingkat PDB tahunan yang diumumkan oleh pemerintah sebagai persentase (\%).

Rumus yang digunakan dalam mengukur pertumbuhan PDB (Kuncoro, 2013) adalah:

$$
P D B=\frac{P D B_{t}-P D B_{t-1}}{P D B_{t-1}} x 100 \%
$$

Berdasarkan pencarian dalam tinjauan literatur dan hasil pengamatan sebelumnya, perumusan hipotesis sebagai berikut:

$\mathrm{H}_{1} \quad$ :Pertumbuhan Ekonomi memiliki pengaruh positif yang signifikan terhadap profitabilitas perusahaan.

\subsection{Teori Pengaruh Inflasi terhadap Profitabilitas}

Inflasi bisa berpengaruh pada ekonomi. Jika inflasi gawat tidak teratasi (hiperinflasi), perekonomian akan lemah dan kacau. Harga naik dengan cepat, orang akan kewalahan menafkahi dan menyamai harga kebutuhan sehari-hari yang terus meningkat. Bagi perusahaan, inflasi mengakibatkan peningkatan beban operasional dan produksi. Ini berdampak pada profitabilitas perusahaan yang bersangkutan bahwa meskipun inflasi telah meningkat, laba yang diperoleh oleh perusahaan tidak mengalami penurunan yang signifikan dan sebaliknya (Adyatmika \& Wiksuana, 2018). Faktor ekonomi makro yang bisa mempengaruhi profitabilitas perusahaan yaitu inflasi, karena kualitas inflasi dapat memperbaharui daya beli (Hasan et al., 2013).

Inflasi adalah periode di mana ada kenaikan harga umum selama periode waktu yang lama. Didalam prakteknya, inflasi bisa dilihat dari pergerakan indeks harga konsumen (Nanga, 2011).

Di dalam penelitian ini, teori Keynes dipakai untuk menjelaskan hubungan antara inflasi dan profitabilitas. Rumus IHK (Sukirno, 2011). yaitu :

$$
I H K=\frac{I H K-I H K_{t-1}}{I H K_{t-1}} x 100 \%
$$

Berdasarkan pencarian dalam tinjauan literatur dan hasil pengamatan sebelumnya, perumusan hipotesis sebagai berikut: 
$\mathrm{H}_{2}$ :Inflasi berpengaruh negatif dan signifikansi terhadap profitabilitas perusahaan.

\subsection{Teori Pengaruh Pertumbuhan Ekonomi dan Inflasi Terhadap Profitabilitas}

Investor tentu akan

menginvestasikan dananya di perusahaan dengan laba yang baik untuk memperoleh keuntungan dari modal disetor.

Peneliti Gitman; Murhadi menyatakan bahwa profitabilitas adalah kemampuan suatu perusahaan untuk menghasilkan laba (Gitman, 2015); (Murhadi, 2013).

Penelitian ini menggunakan ROA yang mencerminkan berapa banyak pengembalian dihasilkan untuk setiap Rupiah dapat di investasikan dalam bentuk asset.

Peneliti Hanafi, rasio ini mengukur kinerja perusahaan untuk menghasilkan keuntungan pada aset, tingkat penjualan dan modal saham (Hanafi, 2014). ROA diperoleh dengan rumus, sebagai berikut:

$$
\text { ROA }=\frac{\text { Net Income }}{\text { Total Asset }} x 100 \%
$$

Dari penjelasan teori di atas dan hasil penelitian sebelumnya, perumusan hipotesis adalah sebagai berikut.

$\mathrm{H}_{3} \quad$ : Produk Domestik Bruto (PDB) dan Inflasi berpengaruh positif terhadap profitabilitas.

\section{METODOLOGI PENELITIAN}

\subsection{Metode Penelitian}

Bursa Efek Indonesia adalah tempat peneliti mengambil data penelitian dikarenakan menyediakan hasil data yang cukup dan akurat melalui www.idx.co.id. Populasi yang diambil oleh peneliti dari perusahaan manufaktur di Bursa Efek adalah 18 perusahaan pada periode 20142017.Dan juga peneliti mengambil tempat penelitian dari data BPS (Badan Pusat Statistik).

Peneliti memakai data sekunder sebagai sumber data didalam penelitian, dimana hasil penelitian tersebut di dapat melalui data yang sudah ada atau tidak secara langsung didapatkan dari subyek atau objek penelitian dan jenis penelitian ialah deskriptif dan pendekatan kuantitatif.

Peneliti Sugiyono, metode yang berlandas atas filosofi positivisme guna untuk mengamati populasi dan sampel. Secara umum, metode pengambilan sampel melalui purposive sampling yang bermaksud untuk menguji hipotesis yang ditetapkan. Penelitian ini bermodel analisis statistik dan angka-angka sehingga disebut metode kuantitatif (Sugiyono, 2016).

Sampel yang memenuhi standar penelitian adalah 12 perusahaan, dengan mengambil 4 tahun penelitian sehingga 12 x $4=48$ sampel akan dipelajari.

\subsection{Model Penelitian}

Pengujian hipotesis dipergunakan untuk mengetahui seberapa besar pengaruh variabel independen berpengaruh pada variabel dependen dalam penelitian ini menggunakan analisis linier berganda.

Perangkat lunak SPSS digunakan oleh para peneliti dalam menganalisis data, model regresi linier berganda berfungsi dalam membuktikan pengaruh beberapa variabel independen dan variabel dependen, (Ghozali, 2016).

Keterangan:

$$
Y=a+b_{1} X_{1}+b_{2} X_{2}+e
$$

$Y=$ Profitabilitas (ROA)

$X_{1}=$ Pertumbuhan Ekonomi (PDB)

$X_{2}=$ Inflasi (I)

$a=$ Konstan

$b_{1}=$ Koefisien Regresi Variabel $X_{1}$

$b_{2}=$ Koefisien Regresi Variabel $X_{2}$

$e=$ Error

\section{HASIL DA PEMBAHASAN}

A. Uji Normalitas 
Alat pengujian dipakai dalam uji normalitas ialah uji One-sample Kolmogorov smirnov. Data akan terdistribusi secara normal apabila nilai asymp sig $>0,05$.

Tabel 1. Hasil Uji Normalitas One Sample Kolmogorov Smirnov Test

\begin{tabular}{|l|l|l|}
\hline \multicolumn{2}{|l|}{} & $\begin{array}{l}\text { Unstandar } \\
\text { Residual }\end{array}$ \\
\hline $\mathrm{N}$ & 40 \\
\hline $\begin{array}{l}\text { Normal } \\
\text { Parameters }\end{array}$ & Mean & .0000000 \\
\cline { 3 - 3 } & $\begin{array}{l}\text { Std. } \\
\text { Deviation }\end{array}$ & .72908322 \\
\hline $\begin{array}{l}\text { Most } \\
\text { Extreme } \\
\text { Differences }\end{array}$ & Absolute & .087 \\
\cline { 2 - 3 } & Positive & .087 \\
\cline { 2 - 3 } Test Statistic & Negative & -.060 \\
\hline \multicolumn{2}{|l|}{ Asymp. Sig. (2-tailed) } & .087 \\
\hline \multicolumn{2}{|l|}{ Berdasarka } & $.200^{\text {c,d }}$ \\
\hline
\end{tabular}

Berdasarkan tabel 1 di atas, nilai Asymp Sig. (2-tailed) diperoleh sebesar $0,200>0,05$ maka data terdistribusi normal.

\section{B. Uji Multikolinearitas}

Tabel 2. Hasil Uji Multikolinearitas

\begin{tabular}{|l|l|l|l|}
\hline \multicolumn{4}{|c|}{ Coefficients a } \\
\hline \multirow{2}{*}{\multicolumn{2}{|c|}{ Model }} & \multicolumn{2}{c|}{$\begin{array}{c}\text { Collinearity } \\
\text { Statistics }\end{array}$} \\
\cline { 3 - 4 } \multicolumn{2}{|c|}{} & $\begin{array}{c}\text { Toleran } \\
\text { ce }\end{array}$ & VIF \\
\hline \multirow{2}{*}{1} & (Constant) & & \\
\cline { 2 - 4 } & LN_PDB & .518 & 1.929 \\
\cline { 2 - 4 } & LN_INFLASI & .518 & 1.929 \\
\hline \multicolumn{2}{|c|}{ a. Dependent variable: LN_ROA } \\
\hline \multicolumn{2}{|c|}{ Berdasarkan tabel 2 di atas, nilai }
\end{tabular}

Toleransi PDB adalah 0,518 dengan nilai VIF 1,929 dan nilai Toleransi inflasi 0,518 dengan nilai VIF 1,929. Dapat disimpulkan bahwa tidak ada multikolinieritas dalam penelitian ini.

\section{Uji Autokolerasi}

Tabel 3 Model Summary ModelSummary ${ }^{\mathrm{b}}$

\begin{tabular}{|l|l|l|l|l|l|}
\hline $\begin{array}{l}\text { Mo } \\
\text { del }\end{array}$ & $\mathrm{R}$ & $\begin{array}{l}\mathrm{R} \\
\text { Squa } \\
\text { re }\end{array}$ & $\begin{array}{l}\text { Adj } \\
\mathrm{R} \\
\text { Squa } \\
\text { re }\end{array}$ & $\begin{array}{l}\text { Std. } \\
\text { Error } \\
\text { of } \\
\text { the } \\
\text { Esti } \\
\text { mate }\end{array}$ & $\begin{array}{l}\text { Durb } \\
\text { in- } \\
\text { Wats } \\
\text { on }\end{array}$ \\
\hline 1 & $\begin{array}{l}.14 \\
0^{\mathrm{a}}\end{array}$ & .020 & -.033 & $\begin{array}{l}.748 \\
53\end{array}$ & $\begin{array}{l}2.34 \\
4\end{array}$ \\
\hline
\end{tabular}

a. Predictors: (Constant), LN_INFLASI, LN_PDB

b. Dependent variable: LN_ROA

Berdasarkan tabel 3 di atas, nilai Durbin Watson adalah 2.344 dan hasil Du 1.6231 adalah $1.656>1.6231<2.344$ sehingga penelitian ini bebas dari uji autokorelasi.

\section{Uji Heterokedastisitas}

Tabel 4. Hasil Uji Heterokedastisitas

\begin{tabular}{|c|c|c|c|c|c|c|}
\hline \multicolumn{7}{|c|}{ Coefficients } \\
\hline & \multirow{2}{*}{ Model } & \multicolumn{2}{|c|}{$\begin{array}{l}\text { Unstandardized } \\
\text { Coefficients }\end{array}$} & \multirow{2}{*}{$\begin{array}{c}\begin{array}{c}\text { Std } \\
\text { Coef }\end{array} \\
\text { Beta }\end{array}$} & \multirow{2}{*}{$\mathrm{T}$} & \multirow{2}{*}{ Sig. } \\
\hline & & B & $\begin{array}{l}\text { Std. } \\
\text { Error }\end{array}$ & & & \\
\hline \multirow{3}{*}{1} & (Constant) & -26.958 & 29.441 & & -.916 & .366 \\
\hline & LN_PDB & 1.005 & 1.079 & .209 & .931 & .358 \\
\hline & LN_Inflasi & .246 & .239 & .231 & 1.029 & .310 \\
\hline
\end{tabular}

Berdasarkan tabel 4 di atas, diperoleh bahwa nilai signifikan pertumbuhan ekonomi adalah 0,358; dan inflasi 0,310; $>0,05$, penelitian ini bebas dari uji heteroskedastisitas.

\section{E. Hasil Analisis Data Penelitian}

Tabel 5. Hasil Analisis Data

\begin{tabular}{|c|c|c|c|c|c|c|c|c|}
\hline \multicolumn{9}{|c|}{ Coefficients $_{a}$} \\
\hline & \multirow[t]{2}{*}{ Model } & \multicolumn{2}{|c|}{$\begin{array}{l}\text { Unstandardize } \\
\text { d Coefficients }\end{array}$} & \multirow{2}{*}{$\begin{array}{c}\text { Sta } \\
\text { nd } \\
\text { Coe } \\
\text { ff } \\
\text { Bet } \\
\text { a }\end{array}$} & \multirow[t]{2}{*}{$\mathrm{T}$} & \multirow{2}{*}{$\begin{array}{l}\mathrm{Si} \\
\mathrm{g} .\end{array}$} & \multicolumn{2}{|c|}{$\begin{array}{c}\text { Collinear } \\
\text { ty } \\
\text { Statistics }\end{array}$} \\
\hline & & B & $\begin{array}{l}\text { Std. } \\
\text { Error }\end{array}$ & & & & $\begin{array}{l}\mathrm{T} \\
\mathrm{ol}\end{array}$ & VIF \\
\hline \multirow{3}{*}{1} & (Constant) & $\begin{array}{l}4.27 \\
5 \\
\end{array}$ & $\begin{array}{l}49.92 \\
8 \\
\end{array}$ & & .086 & $\begin{array}{l}.93 \\
2\end{array}$ & & \\
\hline & LN_PDB & ${ }^{-} .230$ & 1.830 & $\begin{array}{l}- \\
.02 \\
8\end{array}$ & $\begin{array}{l}- \\
.125\end{array}$ & $\begin{array}{l}.90 \\
1\end{array}$ & $\begin{array}{l}.5 \\
18\end{array}$ & $\begin{array}{l}1.92 \\
9\end{array}$ \\
\hline & LN_Inflasi & $\begin{array}{l}- \\
.283\end{array}$ & .406 & $\begin{array}{l}- \\
.15 \\
8\end{array}$ & -6 & $\begin{array}{l}.48 \\
9\end{array}$ & $\begin{array}{l}.5 \\
18\end{array}$ & $\begin{array}{l}1.92 \\
9\end{array}$ \\
\hline
\end{tabular}


Berdasarkan tabel 5 di atas diperoleh persamaan regresi linier berganda sebagai berikut:

$$
\begin{array}{r}
L N \text { ROA }=4,275-0,230 \text { LN PDB } \\
-0,283 \text { LN Inflasi }+e
\end{array}
$$

Interpretasi dari persamaan di atas adalah sebagai berikut:

1. Konstanta dari 4.275 menjelaskan bahwa penelitian di atas adalah positif, ada hubungan langsung antara profitabilitas dengan pertumbuhan ekonomi dan inflasi.

2. Nilai koefisien pertumbuhan ekonomi -0.230 menjelaskan jika diasumsikan bahwa variabel independen di luar model regresi adalah tetap sehingga jika pertumbuhan ekonomi naik setiap satuunit, profitabilitas meningkat sebesar -0.230 .

3. Nilai koefisien inflasi adalah -0.283 menjelaskan jika diasumsikan bahwa variabel independen di luar model regresi adalah tetap sehingga jika inflasi naik setiap satu unit maka profitabilitas meningkat sebesar 0.283 .

\section{F. Pengujian Parsial (Uji-t)}

\begin{tabular}{|c|c|c|c|c|c|c|}
\hline \multicolumn{7}{|c|}{ Coefficients $_{a}$} \\
\hline & \multirow{2}{*}{ Model } & \multicolumn{2}{|c|}{$\begin{array}{c}\text { Unstandardized } \\
\text { Coefficients }\end{array}$} & \multirow{2}{*}{$\begin{array}{c}\begin{array}{c}\text { Stand } \\
\text { Coeff }\end{array} \\
\text { Beta }\end{array}$} & \multirow{2}{*}{$\mathrm{T}$} & \multirow{2}{*}{ Sig. } \\
\hline & & B & $\begin{array}{l}\text { Std. } \\
\text { Error }\end{array}$ & & & \\
\hline \multirow{3}{*}{1} & (Const) & 4.275 & 49.928 & & .086 & .932 \\
\hline & LN_PDB & -.230 & 1.830 & -.028 & -.125 & .901 \\
\hline & LN_Inflasi & -.283 & .406 & -.158 & -.698 & .489 \\
\hline
\end{tabular}
Tabel 6. Uji-t

Berdasarkan tabel 6 di atas, diperoleh hasil sebagai berikut :

1. Pertumbuhan ekonomi dengan nilai signifikansi 0,901 >0,05 dan memiliki $-t_{\text {hitung }}-0,125<-t_{\text {tabel }} 2,01290$ sehingga pertumbuhan ekonomi tidak berpengaruh dan tidak signifikansi parsial terhadap profitabilitas.

2. Inflasi dengan nilai signifikansi 0,489 $>0,05$ dan memiliki $-t_{\text {hitung }}-0,698<-$ $\mathrm{t}_{\text {tabel }} 2,01290$ sehingga inflasi tidak berpengaruh dan secara parsial tidak signifikansi terhadap profitabilitas.

\section{G. Pengujian Simultan Uji F}

Tabel 7 Uji F

\begin{tabular}{|l|l|l|l|l|l|l|}
\hline \multicolumn{7}{|l|}{ ANOVA $^{\mathrm{a}}$} \\
\hline \multirow{2}{*}{ Model } & $\begin{array}{l}\text { Sum of } \\
\text { Squares }\end{array}$ & Df & $\begin{array}{l}\text { Mean } \\
\text { Square }\end{array}$ & F & Sig. \\
\hline \multirow{3}{*}{1} & Regression & .413 & 2 & .206 & .368 & $.694^{\mathrm{b}}$ \\
\cline { 2 - 7 } & Residual & 20.731 & 37 & .560 & & \\
\cline { 2 - 7 } & Total & 21.144 & 39 & & & \\
\hline \multicolumn{2}{|l}{ a. Dependent variable: LN_ROA } \\
\hline
\end{tabular}

Berdasarkan tabel 7 di atas, nilai $-\mathrm{F}_{\text {hitung }}$ $0,368<-\mathrm{F}_{\text {tabel }} 3,20$ dan nilai signifikan 0,694 dengan tingkat kepercayaan 5\% sehingga Ha ditolak dan Ho diterima, kesimpulannya adalah bahwa pertumbuhan ekonomi dan inflasi tidak memiliki efek dan tidak ada signifikansi simultan dari profitabilitas.

\section{H. Koefisien Determinasi $\left(\mathbf{R}^{2}\right)$}

\begin{tabular}{|c|c|c|c|c|}
\hline \multicolumn{5}{|c|}{ Model Summary } \\
\hline \multirow{2}{*}{$\begin{array}{l}\text { Mod } \\
\text { el }\end{array}$} & $\mathrm{R}$ & $\mathrm{R}$ & Adjusted & \multirow{2}{*}{$\begin{array}{l}\text { Std. Error } \\
\text { of the } \\
\text { Estimate }\end{array}$} \\
\hline & & Square & R Square & \\
\hline 1 & .140 & .020 & -.033 & .74853 \\
\hline
\end{tabular}
Tabel 8. Uji-R

a. Predictor: (Constant), LN_INFLASI, LN_PDB

b. Dependent variable: LN_ROA

Berdasarkan tabel 8 di atas, diperoleh nilai $\mathrm{R}$ square sebesar 0,020 , yang berarti bahwa variabel independen yang mempengaruhi variabel dependen adalah $2 \%$ sedangkan $98 \%$ lainnya dipengaruhi oleh variabel lain di luar penelitian ini.

\section{PEMBAHASAN}

A. Pengaruh Pertumbuhan Ekonomi Terhadap Profitabilitas Perusahaan

Peneliti Cahyani dengan judul "Pengaruh Inflasi, Suku Bunga (BI Rate), Produk Domestik Bruto (PDB) Terhadap ROA (Studi Pada Bank Pembiayaan Rakyat Syariah (BPRS) di Indonesia Tahun 2009-2016)". Hasil pengujian 
yang diperoleh yaitu pertumbuhan ekonomi tidak berpengaruh dan tidak signifikansi terhadap profitabilitas. (Cahyani, 2018).

Peneliti Alper \& Anber dengan judul "Bank Specific and Macroeconomic Determinants of Commercial Bank Profitability: Empirical Evidence from Nigeria". Dengan hasil penelitian bahwa pertumbuhan ekonomi tidak mempengaruhi profitabilitas (Alper \& Anber, 2017).

\section{B. Pengaruh Inflasi Terhadap Profitabilitas Perusahaan}

Peneliti Sholiha dan kawan-kawan; dengan judul "Analisis Pengaruh Faktor Makro Ekonomi terhadap Probabilitas Return On Asset (ROA) PT.Bank Mualamat Syariah Indonesia Tbk”. Hasil uji diperoleh bahwa inflasi tidak berpengaruh dan signifikansi terhadap profitabilitas (Sholiha et al., 2019).

Peneliti Alper \& Anber dengan judul "Bank Specific and Macroeconomic Determinants of Commercial Bank Profitability: Empirical Evidence from Nigeria". Dengan hasil penelitian bahwa inflasi tidak mempengaruhi profitabilitas (Alper \& Anber, 2017).

\section{KESIMPULAN}

Berdasarkan hasil penelitian mengenai pengaruh pertumbuhan ekonomi, dan inflasi terhadap profitabilitas pada perusahaan makanan dan minuman di Bursa Efek Indonesia (BEI) periode 20142017 dengan memakai teknik analisis regresi linier berganda, membuktikan bahwa hasil uji F (simultan) variabel PDB dan Inflasi tidak berpengaruh secara signifikansi terhadap profitabilitas. Hasil uji t (parsial) membuktikan bahwa PDB dan Inflasi tidak berpengaruh secara signifikansi terhadap profitabilitas.

Koefisien determinasi dalam penelitian adalah sebesar $74,8 \%$.

\section{REFERENCES}

Adiyadnya, I. N. S., Artini, L. G. S., \& Rahyuda, H. (2016). Pengaruh Beberapa Variabel Ekonomi Makro Terhadap Profitabilitas dan Return Saham Pada Industri Perbankan Di BEI. E-Jurnal Ekonomi Dan Bisnis Universitas Udayana, 5(8), 25792608.

Adyatmika, I. G. P., \& Wiksuana, I. G. B. (2018). Pengaruh Inflasi Dan Leverage Terhadap Profitabilitas Dan Return Saham Pada Perusahaan Manufaktur Di Bursa Efek Indonesia. E-Jurnal Ekonomi Dan Bisnis Universitas Udayana, 3, 615. https://doi.org/10.24843/eeb.2018.v 07.i03.p01

Cahyani, Y. T. (2018). Pengaruh Inflasi, Suku Bunga (BI Rate), Produk Domestik Bruto (PDB) Terhadap ROA (Studi Pada Bank Pembiayaan Rakyat Syariah (BPRS) di Indonesia Tahun 2009-2016). IQTISHADIA: Jurnal Ekonomi \& Perbankan Syariah, 5(1), 58. https://doi.org/10.19105/iqtishadia. v5i1.1695

Deger Alper, A. A. (2017). Bank Specific and Macroeconomic Determinants of Commercial Bank Profitability: Empirical Evidence from Nigeria. International Journal of Finance \& Banking Studies (2147-4486), 6(1), 25.

https://doi.org/10.20525/ijfbs.v6i1.6 27

Eduardus Tandelilin. (2012). Analisis Investasi dan Manajemen Portofolio: Teori dan Aplikasi (Ed. 1). Yogyakarta: BPFE.

Ekasari, N. P., \& Baskara, I. G. K. (2018). Nilai Tukar, Nilai Ekspor, Dan Pertumbuhan Ekonomi Terhadap Profitabilitas Eksportir Food and Beverage Di Bei. E-Jurnal Manajemen Universitas Udayana, 7(8), 4181. 
https://doi.org/10.24843/ejmunud.2 018.v07.i08.p06

Ghozali, I. (2016). Aplikasi Analisis Multivariate Dengan Program IBM SPSS $23 \quad(8$ ed). Semarang: Universitas Diponegoro.

Hanafi, M. M. (2014). Manajemen Keuangan (Cetakan Ke). Yogyakarta: BPFE.

Hasan, N. A., Shaari, N. A., Palanimally, Y. R., Kumar, R., \& Haji, M. (2013). the Impact of Macroeconomic and Bank Specific. Interdisciplinary Journal of Contemporary Research In Business, 5, 2(2013), 106-126.

Kasmir. (2012). Analisis Laporan Keuangan. Retrieved from http://inlislite.usm.perpusnas.go.id/i nlislite3/opac/detail-opac?id=3557

Kasmir. (2013). Bank dan Lembaga Keuangan Lainnya. Jakarta: Rajawali Pers.

Kuncoro, M. (2013). Indikator Ekonomi (Cetakan Pe). Yogyakarta: UPP STIM YKPN.

Lawrence J. Gitman, C. J. Z. (2015). Principles of Managerial Finance (14th Editi). Retrieved from https://www.pearson.com/us/higher -education/product/GitmanPrinciples-of-Managerial-Finance14th-Edition/9780133507690.html

Murhadi, R. W. (2013). Analisis Laporan Keuangan Proyeksi dan Valuasi Saham. Jakarta: Salemba Empat.

Nanga, M. (2011). Ekonomi Makro Teori, Masalah dan Kebijakan. Jakarta:
Erlangga.

Ramadan, I. Z., Kilani, Q. a, \& Kaddumi, T. a. (2011). Factors Affecting Jordanian Banks. Ijar.Lit.Az INTERNATIONAL JOURNAL Of ACADEMIC RESEARCH, 3(4), 180-191.

https://doi.org/10.2139/ssrn.110682 5

Sholiha, H., Studi, P., Pembangunan, E., Ekonomi, F., Bisnis, D. A. N., \& Surakarta, U. M. (2019). ANALISIS PENGARUH FAKTOR MAKRO EKONOMI TERHADAP PROBABILITAS RETURN ON ASSET ( ROA ) PT BANK MUAMALAT SYARIAH INDONESIA TBK.

Sugiyono. (2016). Metode Penelitian Kuantitatif, Kualitatif, dan $R \& D$. Bandung: PT ALFABETA.

Sukirno, S. (2011). Teori Pengantar Makroekonomi. Jakarta: PT. RajaGrafindo Persada.

Suryani, A., Suhadak, S., \& Hidayat, R. (2016). PENGARUH RASIO CAPITAL ADEQUACY RATIO, BIAYA OPERASIONAL PER PENDAPATAN OPERASIONAL, LOAN TO DEPOSIT RATIO, NET INTEREST MARGIN DAN NON PERFORMING LOAN TERHADAP RETURN ON ASSETS (Studi pada Bank Umum yang Terdaftar di Bursa Efek Indonesia Periode 2012-2. Jurnal Administrasi Bisnis S1 Universitas Brawijaya, 33(1), 105-113. 